\title{
Brahms and Schubring: Musical Criticism and Politics at Mid-Century
}

\author{
WALTER FRISCH
}

In 1861-62 there appeared in the Neue Zeitschrift für Musik, Germany's leading music journal since the demise of the Allgemeine Musikalische Zeitung in 1848, a lengthy survey of four composers representative of the "Schumann school." The most space by far-thirtyeight columns, extending over five issues in the spring of 1862 - was given to a close examination of the all the published music of Johannes Brahms, then comprising eighteen opuses. The author, who signed himself with the cipher "DAS," was Adolf Schubring, a friend and admirer of Brahms, and by profession a judge in the town of Dessau.

Although mentioned in passing by Brahms biographers, Schubring's remarkable Brahms essay has never received the close attention it

19th-Century Music VII/3 (3 April 1984). (c) by the Regents of the University of California. merits. Comprising the first substantial critical account of Brahms's music, it is especially valuable for having appeared so early in the composer's career, on the verge of his thirtieth year and the period Tovey called his "first maturity." 1 Schubring makes a fine witness to the early Brahms because, unlike Tovey and the rest of us, he had no knowledge of the composer's later development. And although basically sympathetic, he pulls no punches. Much of the music comes in for strong-and impressively perceptive-criticism.

Interesting in its own right, Schubring's article also opens a broader perspective on the highly "politicized" German musical scene at

\footnotetext{
${ }^{1}$ See Donald Tovey, "Brahms's Chamber Music," in Tovey, Essays and Lectures on Music (London, 1949), p. 243. Tovey's ideas have recently been taken up and developed by James Webster in "Schubert's Sonata Form and Brahms's First Maturity (II)," this journal 3 (1979), 52-71.
} 
mid-century, in which the Rezeptionsgeschichte of the young Brahms plays an important role. It is in this wider (and often amusing) context where we should begin.

\section{I}

Schubring's account of the Schumann school comprised segments 5 through 8 of a twelve-article series entitled Schumanniana, which appeared sporadically over nine years, beginning in the Neue Zeitschrift in 1860 and continuing in the revived Allgemeine Musikalische Zeitung in 1864. (See Appendix for bibliography of the entire series. All page references to articles in the series will be included in the text. All translations are mine unless otherwise noted.) In Schumanniana 10 (December 1863), Schubring offered a charming and characteristically direct explanation of why he undertook the series:

I am a Schumannianer; thus I was driven to write Schumanniana and to have them published if possible in the most widely read music journals. But how was this to be achieved, since there was clearly no music journal which represented the Schumann line, that is, the musical center? I now thought to myself: the Neue Zeitschrift für Musik in Leipzig certainly champions the extreme left; but it was founded by Schumann and will thus surely grant a place to the Schumanniana, even if only out of gratitude to its founder. No sooner thought than done. But then misunderstandings arose. Hoisting the Schumann flag did not help me at all. Since my Schumanniana appeared in the Neue Zeitschrift für Musik, people assumed I must be a New German (p. 193).

At this point in Schubring's article, the editor of the Neue Zeitschrift, Franz Brendel, inserted an exasperated, defensive footnote:

Editor's remark: Because the matter of misunderstandings has been raised, we cannot allow it to go unmentioned that a few appear to have slipped into the above remarks, and we want to take this opportunity to correct them. Our journal does not represent the extreme left; it constitutes the center, but has also willingly granted the former a place. The author is furthermore unaware that for years our journal championed predominantly the Schumann line, so much so that we received on those grounds the same reproaches later directed at our recognition of the New German School. It is Schumann's organ, today even as it was twenty years ago. . . It was not out of gratitude to Schumann that we accepted that [Schubring's] article; our action was principally an acknowledgement of its right to be published.

Author and editor here revive /and neatly encapsulate) a debate that raged hotly throughout musical Germany in the 1850s. Brendel, editor of the Neue Zeitschrift since 1845, was indeed a strong advocate of the New German School, the group of composers gathered physically or spiritually around Liszt. In his journal Weimar often appears as a kind of holy city, as in this observation from a lead article of November 1852, written by Brendel himself: "If I now turn my gaze toward Weimar in particular, it is because Liszt's activity there has created a new spiritual center for the musical life of Germany. While elsewhere at present we see represented more or less only our epoch in its death throes, here [in Weimar] appears the rosy dawn of the future." 2

Brendel's rosy dawn does not seem to rise on the more conservative composers of the time, including the products of Mendelssohn's tenure at the Leipzig Conservatory and the musicians grouped around Schumann. Less than a year later, in October 1853, Schumann responded with his own vision of the future. In a short and sensational article, "Neue Bahnen," Schumann broke his long journalistic silence to proclaim a totally unknown young composer, Brahms, as the one "called to give expression to his times in ideal fashion." In a footnote Schumann drew attention to other "significant talents," including Joseph Joachim, Ernst Naumann, Ludwig Normann, Woldemar Bargiel, Theodor Kirchner, Julius Schaeffer, Albert Dietrich-"not to forget that profound aspirant to great art, C. F. Wilsing, composer of sacred music." He adds, "As bravely advancing heralds I must also name Niels W. Gade, C. F. Mangold, Robert Franz, and Stephen Heller." ${ }^{\prime 3}$

Noticeably absent from this list are Wagner

\footnotetext{
${ }^{2}$ Franz Brendel, "Ein dritter Ausflug nach Weimar," Neue Zeitschrift für Musik 37 (1852), 225.

${ }^{3}$ Robert Schumann, "Neue Bahnen," Neue Zeitschrift für Musik 39 (1853), 185. The article has been translated many times; one of the most colorful (upon which I have drawn in my citations here) is "New Roads," in Robert Schumann, On Music and Musicians, ed. Konrad Wolff, trans. Paul Rosenfeld (New York, 1946), pp. 252-54.
} 
and Liszt, or any of the other New Germans, such as Raff and Cornelius. On Schumann's revisionist map, the most promising paths in modern music pointed neither toward nor away from Weimar.

Only three months after the appearance of "Neue Bahnen," Schumann was sent to Endenich and never had the chance to promote further in print either Brahms or the other composers he had praised. Nor did the Neue Zeitschrift follow his lead. Throughout the 1850s the journal continued to publish lead articles about Liszt, Wagner, and their followers; the most frequent authors were Richard Pohl /alias "Hoplit"l, Theodor Uhlig, Brendel, and Liszt and Wagner themselves. Brendel does seem to have had a more equitable policy for reviews or $R e$ censionen of new music; several of the inhabitants of Schumann's footnote were so honored, including Kirchner, Dietrich, Bargiel, and Schaeffer. Conspicuously absent from the columns of the journal, however, was any account of Brahms's music, which began to appear in print late in 1853 , soon after Schumann's article.

Finally, in July and December 1855, Pohl devoted three lead articles (covering about sixteen columns) to Brahms. He attempted to excuse the journal's "persistent silence" on this subject by observing that Schumann's article had made it difficult for anyone else to write about Brahms in the same pages and perhaps express a different opinion. Moreover, he explained, the Neue Zeitschrift had wanted to wait to pass judgement until a sufficient number of Brahms's works had appeared. By the time of Pohl's writing, ops. 1-9 were in print.

Despite their considerable length, Pohl's articles say little of substance, and what is said is far from flattering. Pohl's critical/analytical judgements are vague and unilluminating. $\mathrm{He}$ seems not to have studied the scores, observing only that they "are very difficult to approach with logic; they go beyond every consequence and presupposition, yet could not on that account be valued as god-given. His [Brahms's] work is thus uneven, its invention unstable; at times it appears whimsical. It is not steady because it is not sufficiently thought out, and above all there is missing that style which per- mits artistic subjectivity to reach objective expression. ${ }^{\prime 4}$ Drawing pointedly on the categories Schumann had used, Pohl says it is not yet clear whether Brahms will prove to be a "talent" or a "genius." He then begs off a close examination of the music, promising to look at ops. 1-9 in another article.

No article was forthcoming, and the Neue Zeitschrift again drew a veil of silence over Brahms. In 1856 Schumann died without ever seeing his opinions vindicated (or repudiated) in the journal. Schumann's creative legacy, however, was a popular topic, and, to judge from the Neue Zeitschrift, Brahms was neither the sole nor even the principal heir. In March 1858 Hans von Bülow contributed a lengthy lead article entitled "Ein Schüler Robert Schumann's"; its subject was not Brahms or any of the other bedeutende Talente, but Karl Ritter, whose ops. 1-5 had recently been issued by Breitkopf und Härtel. In his preamble Bülow distinguishes between the literal meaning of Schüler and its more figurative one, which he finds much abused. Ritter was one of Schumann's few real pupils (this seems to be true), not one of those (Bülow mentions no one by name) who attain their musical identity merely by attaching the suffix -ianer to the master's name. Moreover, Bülow explains, Ritter's music reveals him to be a genuine inheritor of the Schumann tradition. ${ }^{5}$

As charted by the Neue Zeitschrift in 1858, then, the new paths-even those leading from Schumann himself-seem to have bypassed Brahms altogether. ${ }^{6}$ This the composer would surely have noticed. The documentation of his discontent is the famous manifesto he, Joachim, and a few other close associates published in the Berlin Echo in March 1860. They charged that the Neue Zeitschrift "constantly spreads the notion that all serious, striving musicians are basically in agreement with the party line

\footnotetext{
${ }^{4}$ Hoplit [Richard Pohl], "Johannes Brahms," Neue Zeit schrift für Musik 44 (1855), 263.

"Hans von Bülow, "Ein Schüler Robert Schumann's," Neue Zeitschrift für Musik 48 (1858), 101-02.

${ }^{6} \mathrm{Brahms}$ did, however, receive more attention in other periodicals. A substantial and sympathetic account of his ops. $1-10$ by Carl Debrois van Bruyck appeared the 25 September 1857 issue of the Wiener Zeitung.
} 
pursued by it, that in the compositions of the leaders of said party they recognize works of artistic value, and that the contest for and against the so-called Music of the Future has been concluded, especially in Northern Germany, in its favor."

\section{II}

It was in this highly charged musico-political context that four months later Adolf Schubring began his Schumanniana series in the Neue Zeitschrift. Schubring (1817-1893) had written his first article about music in 1847, a review for the same journal of an opera by his fellow Dessauer Friedrich Lux. He then seems to have lain aside his pen for over a dozen years, perhaps to pursue his full-time career as a judge-a profession that seems to have been virtually preordained, as all the Schubring men were either judges or clergy. ${ }^{8}$

Schubring cultivated numerous other interests as well. A genuine Gelehrte, he spoke or read a dozen languages, including Sanskrit, Greek, Latin, and Hebrew. His chief avocation, however, was music, an area in which the Schubring family had one prominent connection: Adolf's step-brother Julius had been a close friend of Mendelssohn and had prepared the librettos for the two oratorios St. Paul and Elijah.

Like many readers of "Neue Bahnen," Schubring became interested in Brahms very early on; in his case, however, the interest soon developed into passionate enthusiasm. The first letter in the published correspondence /which includes only Brahms's letters to Schubring) dates from 4 January 1856. Having studied Brahms's scores closely, Schubring had bombarded the composer with queries and comments about possible printing errors, appropriate tempos, and other technical matters. He was evidently uncertain how his amateur's intensity would be received, but the composer /sixteen years his junior) responded warmly, "Be assured that a letter from you (hopefully, in any case, about new compositions) will always give

${ }^{7}$ Cited in Hans Gal, Johannes Brahms: His Work and Personality, trans. Joseph Stein (London, 1963), p. 36.

${ }^{8} \mathrm{Max}$ Kalbeck provides a good biographical sketch of Schubring in his introduction to the Brahms-Schubring correspondence; see Johannes Brahms, Briefwechsel, vol. VIII, ed. Max Kalbeck (Berlin, 1915), pp. 161-83. me the greatest pleasure." 9 The two men met for the first time later that month when Brahms visited Dessau to become the godfather of Schubring's son Max Johannes.

According to a brief memoir Schubring's eldest son Richard provided Max Kalbeck for the introduction to the correspondence, Brahms would arrange for proof copies of new works to be sent directly to Dessau, and would await Schubring's (private) comments. "How he beamed when a new opus by Brahms arrived at our house," the young Schubring reports, explaining that his father would immediately organize informal performances at home, often leading larger works from the piano.

It was not until 1862 that Schubring ventured into print on the subject of Brahms. He began his Schumanniana series, as he implies in the passage cited above, to offer readers an alternative to Brendel's "leftist" coverage and, more importantly, to revive interest in the music, the ideals, and the legacy of Robert Schumann. Schubring's colorful prose style (and, of course, the title) is clearly modelled on Schumann and Schumann's own idol, E. T. A. Hoffmann.

The first four of the dozen installments deal with editorial and analytical issues in Schumann's music, including (in no. 3) an intelligent account of the differences between the first and second editions of the early piano music. Schubring prefers the more adventurous original versions. ${ }^{10}$ In no. 4 he elaborates an idiosyncratic, though suggestive, view of music history and of Schumann's place in it. He proposes three eras according to categories generally applied to the visual arts: the architectonic, the plastic, and the painterly ("malerisch"). The music of J. S. Bach makes the transition between the first two eras, that of Schumann between the latter two.

The stage is then set for Schumanniana 5-8, Schubring's treatment of Schumann's true successors, the Schumann'sche Schule. He begins:

In order to characterize briefly the schools that presently dominate musical Germany, we may say that

\footnotetext{
${ }^{9}$ Brahms, Briefwechsel VIII, 186.

${ }^{10}$ Schubring prepared the first critical editions of Schumann's Davidsbündlertänze, op. 6; Études symphoniques, op. 13; and F-Minor Sonata, op. 14. These were published by Julius Schuberth in 1862. See Kurt Hofmann, Die Erstdrucke der Werke von Robert Schumann (Tützing, 1979), p. xv.
} 
one consists of those who place the most emphasis on the (old) form, the other on (new) content; the third, standing in the middle, places equal weight on form and content. That the composers of this school are interested chiefly in pouring new content into the old, time-tested forms, does not necessarily preclude that the content, since it is in fact new, expands, breaks through, or transcends these forms. I would like to be permitted to call this the Schumann school for short, because the composers belonging to it are either genuine pupils of Robert Schumann, or at least perpetuate his spirit and direction. These comprise the genius-endowed Johannes Brahms and J. Joachim, and the talented Carl Ritter, Theodor Kirchner, and Woldemar Bargiel. In his latest works Joachim Raff has also joined this school (p. 53).

Schubring's "Schumann school" adopts a broader admission policy than Bülow's; he clearly has little use for the latter's pedantic distinction among Schüler. ${ }^{11}$ Although Schubring may open the doors a bit too wide in accepting $\mathrm{Raff}$-one wonders what the reaction at Weimar was to this-he has assembled a relatively homogeneous group, four of whom had already received strong report cards from Schumann himself in 1853. Presented in ten installments during 1861-62, each one a lead article, Schumanniana 5-8 comprise detailed examinations of the music of Ritter, Kirchner, Bargiel, and Brahms. (Schubring promised to treat at a later time the music of Joachim, of which little had appeared. He never did, probably because Joachim soon stopped composing actively. He did, however, return briefly to Brahms in nos. 11 and 12 of $1868-69$.)

III

Schubring begins the Brahms segment, appropriately enough, with an extended quotation from "Neue Bahnen," then describes the skepticism with which the article was at first received. Brahms's music is still not very well known, he observes, largely because it is so difficult both to understand and to perform. Also to blame, he notes, is the "unfortunate fragmen-

\footnotetext{
${ }^{11}$ In 1863 Bülow resumed the debate over admission to the Schumann school, and seems to have changed his policy. In a Nachtrag to Schubring's articles, he claimed that Schubring had unjustly neglected the music of Adolf Jensen. See Bülow, "Einige Worte über Adolf Jensen, als Nachtrag zu den Schumanniana im vorigen Jahrgang dieser Blätter," Neue Zeitschrift für Musik 59 (1863), 145-48.
}

tation of musical Germany." While the battle rages, he adds, "I, who have also sworn allegiance to the Schumann banner, will in the meantime await tranquilly the pronouncement of the final, conclusive judge, 'Time' (if I err, at least I err in good company); I will not be polemical, but will rather be thankful that friend Brendel has granted a welcome little spot in his journal for me occasionally to unburden my heart" (p. 94).

Schubring divides Brahms's works into three phases or periods; the model of Beethoven criticism would seem already to be having an influence. "The most recent works, ops. 11-18, are clear wine compared to the fermenting new wine of ops. 1-6. Between the two ops. 7-10 are like a transitional group of less definite, more variable coloring" (p. 95).

Schubring's analyses betray a particular prejudice in favor of thematische Arbeit, the compositional technique identified by countless German writers as the hallmark of the Viennese classicists. In Schumanniana 11, a later installment, Schubring reveals both his understanding and his esteem of thematic work (as I shall translate it):

Thematic work is the logic of music. He who does not remain at his musical task, the theme; he who does not understand how to work up the individual motives and motivic particles of the theme into new characteristic shapes by means of mosaic combination, continuation, expansion; he may for a while-if he has the tools-delight the untutored multitudes with his potpourris, or startle them with prickling harmonies, tone colors, and orchestral effects achieved by simple means. But a logical musician he is not (p. 49).

A critic with this kind of mind-set will find /and has always found) much to admire in Brahms. Schubring must be counted the first of many to voice enthusiasm about Brahms's remarkable powers of thematic logic. He employs elaborate musical examples to set forth all the "new characteristic shapes" Brahms creates from his themes in the principal instrumental works of ops. 1-18.

But Schubring's is no blind admiration. He discovers distinct, and not altogether pleasing, differences between the thematic work of Brahms and his forbears; these are especially
WALTER

FRISCH

Brahms and Schubring 
apparent in the three sonatas, ops. 1,2, and 5. Of the C-Major, op. 1, he observes shrewdly:

One sees that Brahms is using the old thematic art of Haydn and Beethoven, and yet his work makes a very different impression from theirs. The use of imitation, increasing from the seventh, to the ninth, to the eleventh, gives the thematic work a strange character. When other voices are added as filler, the double counterpoint becomes ponderous and bloated, or at least loses that transparent simplicity which alone is suitable to the nature of arabesques. And since Brahms has already placed the most natural and pleasing of his thematic interweavings in the exposition, in order to bring about the necessary build-up in the development he must often have recourse to forced and harsh sonorities. Thus, especially in the development, he has repeatedly overstepped the limit of beauty; and thus it has happened that in his first sonata movement Brahms provides us with an image that is superb and original, yet overloaded with glaring contrast (p. 96).

Schubring here articulates elegantly the flaws that later commentators, even sympathetic ones (including myself), have found in Brahms's sonata forms. Brahms usually "develops" material so thoroughly and compellingly in the exposition that there is little left for the development section to do; here he often resorts to elaborate counterpoint, which can sound labored. ${ }^{12}$

Schubring has greater admiration for Brahms's thematic logic in the F\#-Minor Sonata, op. 2. (He seems unaware that it was composed before op. 1.) He characterizes the differences between the two works in these terms: "The thematic work in Brahms's first sonata consists chiefly of taking a theme that appears fully formed right at the beginning, then splitting it up into particles, and combining these particles into new shapes in the manner of a mosaic. The $F \#-M i n o r$ Sonata adopts the opposite procedure. Its principal and subsidiary melodies originate from mosaic particles before our very eyes" (p. 101). Schubring's phrase "vor unseren sichtlichen Augen" captures well the magic of op. 2, in which dazzling thematic transformations take precedence over the more sober kind

${ }^{12}$ See my discussion of this issue in Walter Frisch, Brahms and the Principle of Developing Variation (Berkeley and Los Angeles, 1984), pp. 121-22. of thematic development characteristic of op. 1

As Schubring observes, this procedure spans the entire $F \#-M i n o r$ Sonata: the principal themes of all four movements are drawn from the initial head motive. While most other sonatas built on a single theme are marked by "aridity"-with the notable exception of Liszt's gestaltungsreiche Sonata in B Minor-Brahms has "solved the difficult problem in a truly ingenious way. He has managed to transform his basic motive more or less recognizably through rhythmic alteration, through displacement in other chord positions, and through exact or retrograde inversion, thereby creating themes and melodies of the most striking contrast" (p. 101). In a large group of musical examples Schubring numbers the notes of the main theme from 1 to 7 , then demonstrates the successive metamorphoses.

He finds Brahms's attempt at motivic uniformity less persuasive in the first movement of the F-Minor Sonata, op. 5. The initial appearance of the head motive makes for a "truly splendid" opening, "but the motives of all the thematic groups are derived from this basic motive, whose initial energy becomes dissipated when the subsidiary motives are extended, principally by means of augmentation. That is the reason Brahms has not succeeded this time in keeping us continuously spellbound. Although individual moments are outstanding ... at others the impression of a certain feebleness and stasis comes over us. The more powerful the upward surge which has preceded, the more noticeable this impression becomes" (p. 102).

While most other commentators have been content merely to admire the motivic "unity" of this sonata, Schubring proves himself remarkably acute in explaining how this unity may in fact be a flaw: because of its heavyhanded rhythmic style and articulated phrase structure, Brahms's obsessively monomotivic discourse does indeed give the first movement of op. 5 a sense of stagnation and clumsiness. Such observations seem to me the best kind of musical criticism: they are based on careful analysis of musical techniques (in a musical example Schubring displays the various permutations of the head motive), yet go beyond mere structural analysis to assess the success or failure of these techniques. 
Schubring prefers the sonata's Andante in $\mathrm{A} b$ major. Brahms published this movement with an epigraph, a stanza from a poem by Sternau, which provides the basis for Schubring's imaginative commentary. "It is program music," he says, "one of the most beautiful moonlight poems ever created." Anticipating recent commentators by well over a century, Schubring elaborates a program involving the zwei Herzen of the poem. ${ }^{13} \mathrm{He}$ even thereby devises a rationale for the movement's concluding in the subdominant, $\mathrm{D} b$, a phenomenon unique in Brahms and a stumbling block for "absolutist" analysts. Schubring notes the resemblance of the coda theme to a folk melody which had become popular at mid-century when fitted to a poem by Wilhelm Hauff, Treue Liebe, about a soldier longing for his girl friend during a lonely night watch. ${ }^{14} \mathrm{He}$ imagines her in her Kämmerlein, saying her evening prayers and thinking of him. "The situation is now different than when his beloved descended to him," explains Schubring, "and therefore the Ab Andante concludes with a pious Adagio in Db major" (p. 103).

After treating the early instrumental works, Schubring considers the two song collections, ops. 3 and 6 . Although the song medium prevents the kind of elaborate counterpoint encountered in the piano sonatas, "a contrapuntist like Brahms could not restrain himself from employing his art in at least a few Lieder" (p. 104). He points especially to the subtly canonic texture of Liebestreu, op. 3, no. 1, and to the less subtle Liebe und Frühling, op. 3, no. 2. Schubring also patiently details various errors of declamation in the songs, thus becoming the first of many critics to accuse Brahms of insufficient attention to prosody. (In one case he also blames a poet, Eichendorff.)

Schubring sees ops. $7-10$ as comprising a

\footnotetext{
${ }^{13}$ Two recent programmatic interpretations of the movement are Detlef Kraus, "Das Andante aus der Sonate op. 5 von Brahms: Versuch einer Interpretation," in Brahms Studien 3 (1979), 47-51; and George Bozarth, "Brahms's Lieder ohne Worte: the Poetic Andantes of the Piano Sonatas, Ballades, and Intermezzi," paper read at the International Brahms Conference, Washington, D.C., May 1983.

${ }^{14}$ The song can be found in Friedrich Silcher, 100 Volkslieder für eine Singstimme mit Begleitung des Pianoforte, rev. Alfred Dörffel (Leipzig, n.d.), p. 76.
}

transitional period in Brahms's development. "When the new wine has completed its fermentation and has cleared up," he observes, resuming his œnological metaphor, "then begins the most dangerous period for the 'flickering wine' [flackern Wein]; the more fiery the growth, the more dangerous it is" (p. 109).

The B-Major Piano Trio, op. 8, belongs "half to this transition period, half still to the earlier Sturm und Drang period." This is, of course, the one work from this period that Brahms reworked extensively; a revised version was issued by Simrock in 1891. Numerous commentators have compared the two versions, usually faulting the earlier for its youthful excesses and praising the latter for its mature, seasoned restraint. Schubring had no such comparative basis for his judgement, of course. It is therefore remarkable that so many of his objections to the trio correspond closely to the second thoughts Brahms himself had in 1889-90. Whether this correspondence shows an actual influence of Schubring on the composer, or only an impressive prescience, we can only guess.

Schubring's favorite movement is the scherzo, which underwent the least amount of recasting. $\mathrm{He}$ is considerably less enthusiastic about the first movement, which he suggests shares with the C-Major Piano Sonata the error of too much thematic material, as well as an unfortunate tendency to "padded counterpoint and overladen polyphony." As might be expected, Schubring admires the opening melody-one of the most splendid themes in all of Brahms-but is dismayed that "after a few bars the violin cannot restrain itself from throwing in a superfluous phrase in the manner of a canary-a phrase that is unnecessary because it does not belong to the theme and is not used any more in later developments" (p. 109). Brahms eventually came to the same decision, removing the violin obbligato of $\mathrm{mm} .6-7$ and 9-12 in his revision. This was indeed the only substantive change he made in the first group.

Schubring is especially appalled at the "bizarre eccentricities" of the recapitulation, where Brahms interpolates a massive fugato in place of the second group (at m. 354):

First Brahms begins a four-voiced fugue on the ... brooding third theme; from the initial imitation on
WALTER FRISCH

Brahms and Schubring 
this fugue becomes virtually opaque and goes awry in the disposition of the voices, which trip over themselves; this opacity increases in the very cramped stretto, which follows after only four (quite rigid) imitative entries [m. 385]. Soon it is no longer possible to govern the troops, which have tangled themselves into a knot. The whole thing disintegrates into a frenzied rout (a canonically imitative episode [m. 396]), until the reserves of the first theme move in as protection [m. 410]. But in the end they too are unable to resist the impact and let themselves be swept away in the general whirlpool [m. 435]. Here the passionate and the characteristic celebrate their triumph, while beauty sorrowfully covers her face (p. 110).

In 1890 Brahms completely overhauled the second group and the recapitulation. The battlefield was swept clean of the corpses, and a single elegant (if somewhat stiff) second theme placed on duty to guard against any further contrapuntal skirmishes.

Schubring considers the Variations on a Theme of Schumann, op. 9, and the Ballades, op. 10 , as Brahms's last flings in a freer, unselfconscious romantic style. They were, as he notes, followed by a long public silence, a study period from which Brahms emerged into a new and very different neo-classical idiom, beginning with the First Serenade, op. 11, published in 1860. Though grandiose, Schubring's assessment gives a fundamentally accurate picture of what Brahms must have been thinking during the hiatus:

Brahms may well have felt that the path he had trodden up to now was a remote dead-end of Romanticism; with all his might he turned back his Pegasus; since there was still time, he turned it back from the hunt of vague and intangible misty shapes, back to the eternally clear forms and the holy realms of the classics. . . Seven years of work [Schubring means 1854-61], a long time, even so long as Jacob served the rich Laban to win Rachel; seven years, a short time considering the reward gained thereby. To acquire the rich heritage of Beethoven and Schumann is truly worth the sweat of nobles (p. 111).

Of Brahms's latest period, comprising ops. 11-18, Schubring notes, "had there been no name on the title page, no one would have guessed Brahms, so different are they in character and in their whole demeanor from the works of the earlier period" (p. 111). The D-Major Serenade, however, "still betrays the study lamp";
Schubring traces the influence of (or the borrowing from) at least six composers, including Haydn, Mozart, Beethoven, Mendelssohn, Schubert, and Schumann. (He does not miss, of course, the resemblance of the opening theme to the finale of Haydn's "London" Symphony.) Schubring finds the serenade an uneven work, in part because the first scherzo and trio and the Adagio are too large for their context; they would be more appropriate to a "symphony." The closing group of the first-movement exposition (m. 177) comes in for similar criticism. Although its thematic content can be traced back to the triplet motion in second group, Schubring observes, one must still ask, "Why all the noise? This is supposed to be a serenade, thus music of a cheerful, or at least gentle character, and not a symphony."

Did Schubring know that Brahms had in fact entitled his work Sinfonie-Serenade für grosses Orchester, but had crossed out the first part of this heading in the autograph ${ }^{15}$ His objections to the work, at any rate, seem surprisingly small-minded, based more on semantic than musical issues. (One is reminded of Bülow's pedantic definition of Schüler.)

The analysis of the serenade also brings out one of Schubring's shortcomings as a critic, a tendency to carry his enthusiasm for thematische Arbeit too far by exaggerating relationships between the different themes of a work. He suggests that "all themes of all six movements are drawn from the basic opening idea, some, admittedly, transformed almost beyond recognition. I have demonstrated such thematic unity in the $F_{\sharp}$-Minor Sonata to the reader's satisfaction, I hope; but here I must forego such proof, since it could be adduced only in an elaborate manner and through many secondary deductions" (p. 112). It is not surprising that Schubring declines to support his claim. For what he was able to demonstrate in op. 2-where the various themes are indeed so related-would be considerably more difficult to show in op. 11.

Brahms was later to take his friend to task for this kind of analysis. In Schumanniana 12

\footnotetext{
${ }^{15}$ The autograph is located in the Hessische Landes- und Hochschulbibliothek in Darmstadt; a microfilm copy is held at the Toscanini Memorial Archives in the Music Division of the New York Public Library.
} 
(1869) Schubring claimed that "all the themes" in the third movement of the German Requiem ("Herr, lehre doch mich") were derived from the "three main themes," which he presented in musical examples that are difficult to decipher (p. 10). Responding politely but firmly, Brahms wrote to Schubring: "I disagree that in the third movement the themes of the different sections have something in common.... If it is nevertheless so-I deliberately call back nothing from my memory-I want no praise for it. . . If I want to retain the same musical idea, then it should be clearly recognized in each transformation, augmentation, inversion. The other way would be a trivial game and always a sign of the most impoverished invention." 16 For Brahms, the kind of superficial resemblances pointed out by Schubring clearly constitute "the other way."

Schubring regards the D-Minor Piano Concerto, op. 15, as the greatest work Brahms has yet produced. In it Brahms seeks to follow the path laid out by Beethoven's concertos, although "only in the Adagio and in the last half of the finale does he reach his lofty goal completely. The first movement ... suffers at times from certain harshnesses and rough edges, and from counterpoint that is too thick (a tendency I have often criticized); one might even suppose that the conception and first version of this movement date back to an earlier time" (p. 118).

As in the case of the original title for op. 11, we are led to wonder whether Schubring had "inside" information about the concerto, whose origins did indeed date back to 1854 . It is clear that in preparing this portion of his article Schubring got assistance from Brahms, who must have showed or loaned him the autograph full score. This score was not published until 1873; in 1861 Rieter-Biedermann had issued only the individual orchestra parts and a Clavierauszug, which included the solo part and cues for the orchestral passages between solo statements. In his article Schubring discusses details of orchestration he could only have discovered (or discovered with reasonable ease) in the full score. One remark in the article clearly suggests that Schubring consulted the auto-

\footnotetext{
${ }^{16}$ See the letter in Brahms, Briefwechsel VIII, 216; see also my discussion in Frisch, Brahms and the Principle of Developing Variation, pp. 30-32.
}

graph: he notes that the Adagio bears an inscription, "Benedictus qui venit [Schubring mistakenly writes 'venis'] in nomine Domini." (He does not speculate on what the phrase means in this context-a problem which has long stumped Brahms scholars. $)^{17}$

One must admire Schubring's thoroughness in seeking out the autograph, and even in verifying one point with the composer before going to print. He asked Brahms to confirm that the $\mathrm{C}$ is natural and not sharp in the descending bassoon line that accompanies the final appearance of the main theme in the coda of the slow movement (m. 96). In a letter of February 1862 Brahms replied that $\mathrm{C}$ q was indeed "richtig." In the published article Schubring observes that the Cq makes an "odd impression" on an ear accustomed to the earlier diatonic $\mathrm{C} \#$.

Schubring concludes his survey with Brahms's most recent publication, the Sextet in B b, op. 18, "which we naturally expect to constitute the grandest, deepest, most significant of this series of masterworks. But we are wide of the mark: it is merely the loveliest, most beautiful, and most mature. Here is Mozart redivivus, not that old Mozart of the last century, but Mozart as he would write if he were young today: clear, naive, simple, lovely, and yet new, fresh, captivating, artistic" (p. 128).

Although charmed by the work as a whole, Schubring is puzzled by the scherzo. The music itself seems to demand a relatively relaxed tempo, but Brahms has indicated Allegro molto. "Notes and tempo indications contradict one another," Schubring observes, and then goes on to propose his own precise tempos. "In the present case I adhere exclusively to the notes and play the piece so that in the scherzo the measure equals 78 ; the trio should not be faster than 94 , the coda 112 " (p. 128). The scherzo is also too brief in proportion to the rest of the work. "The time for these small pieces in $\frac{3}{4}$ meter is past," he complains. "I find fault with Brahms for insisting so obstinately on 3 time and the small Haydnesque minuet when he has

\footnotetext{
${ }^{17}$ This page of the autograph is reproduced in facsimile in Constantin Floros, Brahms und Bruckner: Studien zur musikalischen Exegetik (Wiesbaden, 1980), p. 147. Floros also offers a stimulating new interpretation of the inscription (pp. 144-46).
}

WALTER FRISCH Brahms and Schubring 
already created much of significance in the expanded Beethovenian scherzo form."

There is certainly some justice to Schubring's criticism: the scherzo of op. 18 does seem too small-scale for its context. Brahms himself seems to have been aware (or perhaps was made aware) of a scherzo "problem," for after the sextet he turned away from the "Haydnesque" kind of movement. In the two major works completed in the fall of 1861, the Piano Quartets in G Minor, op. 25, and A Major, op. 26, he experimented with other third-movement types-in op. 25 a genial allegretto that was to become one of his trademarks, and in op. 26 a scherzo and trio both in extended sonata form.

The scherzo of op. 18, as well as the general neoclassical tone of the entire work, bring Schubring to ask, "Has Brahms then forgotten so completely that way into the romantic land, which used to be so dear and true to him?" His answer forms the conclusion to the series on the Schumann school:

Yet why should I worry about Brahms? His genius will continue to lead him along the proper path, as it has done up to now. Let Brahms for a while take pleasure in awakening the echo of the valleys with his idyllic reed-pipe; soon, you can wager on it, when the young eagle considers his wings full-grown, he will rise to that highest summit which the tiny Myrmidons are allowed only to gaze at from afar. Brahms blows with equal virtuosity the battle trumpet and the shepherd's pipe; he possesses the gift to express in tones sorrow and joy, hate and love, grief and delight, all with equal power, truth, and beauty. He understands how to be alternately ancient and modern, classic and romantic, ideal and real-and after all, I believe he is appointed to blend both these eternal opposites within art into a higher unity in the magic cauldron of humor, and to reach in music the position occupied in poetry by Goethe ... whose demonic nature underwent similar transformations and purifications.

These words may sound presumptuous, but stopped horns do not suffice when it is a matter of arousing the greater public, which does not yet seem to have any idea what a colossal genius-one completely the equal of Bach, Beethoven and Schumann-is ripening in the young Hamburg master (p. 1281 .

Despite his high-flown style and exaggerated (and occasionally mixed) metaphors, Schubring captures here something of the essence of
Brahms's art, especially its powerful fusion of classic and romantic qualities. This kind of observation, as well as the association of Brahms with the other two "B"s, seem commonplace today, of course. But for someone writing in 1862 it was prediction, not hindsight. And it represents a prediction arrived at through unusually sensitive and responsible musical criticism.

\section{IV}

Schubring's article appeared at an important moment in Brahms's career. After a neo-classical retrenchment the composer had embarked on the ambitious works of his first maturity, to comprise the $\mathrm{B} b$ Sextet, op. 18 (really a transitional work), the two Piano Quartets, ops. 25 and 26, the Piano Quintet, op. 34, and G-Major Sextet, op. 36, the E-Minor Cello Sonata, op. 38, and the Horn Trio, op. 40. At about the time that Schubring was writing his article, Brahms was at work on another piece of which he was especially proud, the Handel Variations, op. 24. He sent a (manuscript) copy of the variations to Schubring in April 1862 with the remark, "I am fond of it and value it particularly in relation to my other works." 18

Indeed, Brahms held the variations in such esteem that he decided to submit them /calling them his Lieblingswerk) to the prestigious German music publisher Breitkopf und Härtel rather than his (by now) regular publisher, Rieter-Biedermann. At first Breitkopf turned down the piece, but finally accepted it when the insistent composer lowered his fee by a third. ${ }^{19}$

Brahms was carrying on these negotiations at the very moment Schubring's article appeared in the Neue Zeitschrift, and he clearly understood the potential value of favorable criticism. As he wrote to Schubring (in the same letter of April cited above), "If a work particularly appeals to you, then I am of course very pleased if you act publicly on its behalf in as friendly a fashion as you do now. Not only does the warm sympathy delight me personally, but it is good in other respects. I am afraid that my relation-

\footnotetext{
${ }^{18}$ Brahms, Briefwechsel VIII, 192.

${ }^{19}$ See the letters exchanged between Brahms and Breitkopf und Härtel in Brahms, Briefwechsel XIV, ed. Wilhelm Alt mann (Berlin, 1921), pp. 60-68.
} 
ship to the publishers may well not remain as friendly as it is now, if people don't begin to care about my works."

Like most artists, Brahms enjoyed positive remarks from a critic but was made uncomfortable by negative ones, which, as we have seen, abound in Schubring's article. Although he frequently invited comments from close friends (including Schubring) about works still in manuscript, he was ambivalent about public criticism. "You wield a fast, sharp pen," he wrote Schubring in February 1862, "but perhaps consider too little that you seldom say anything new to the artist, whereas he in return views and judges you and your remarks from a more advantageous perspective. ${ }^{\prime 20}$ Here is a classic expression of the stance an artist typically assumes toward a critic. Brahms's unmistakable message is: you only write about music; I create it.

Later on, while the article was appearing in print, Brahms was more contrite-although still defensive-writing to Schubring:

With great joy, with greater shame have I read your essays on my works, so far as they reached me up to now.

I am very tempted to take my works in hand, set them beside what you've written, and then to excuse and defend many things. The opposite [i.e., admitting

${ }^{20}$ Brahms, Briefwechsel VIII, 190. you are right], would clearly be easier to do, but I know better than to carve my own flesh. ${ }^{21}$

For Schubring, Schumanniana 8 represented a belated, much needed vindication of Schumann's "Neue Bahnen": it aimed to show that despite some youthful flaws in his work, Brahms was indeed destined to earn a place among the great German composers. In a more literal sense too, Brahms was about to set out on a "new path": just four months after Schubring's article, in September 1862, he made his first trip to Vienna in order to broaden his reputation as a performer and composer. In November he played some of his most recent works, the Handel Variations and the two piano quartets, and attracted the attention and support of a critic much more powerful than Schubring, Eduard Hanslick. ${ }^{22}$

Within a decade Brahms would settle in Vienna, making it his permanent physical and artistic home. Schubring's comprehensive critical account of his early music may well have helped to build the self-assurance and the public image-both the inner and outer conditionsnecessary to undertake the first fateful journey.

\footnotetext{
${ }^{21}$ Brahms, Briefwechsel VIII, 191.

${ }^{22} \mathrm{Hanslick}$ 's review of Brahms's first public concert in Vienna, given in November 1862, is included in Eduard Hanslick, Music Criticisms 1846-99, trans. and ed. Henry Pleasants (Baltimore, 1963), pp. 82-86.
}

WALTER FRISCH Brahms and Schubring

\section{APPENDIX \\ Schumanniana by Adolf Schubring}

1. "Über Declamationsfehler in Schumann's 'Paradies und die Peri'," Neue Zeitschrift für Musik [hereafter NZfM] 52 (1860), 210-11.

2. "Schumann und der Grossvater," NZfM 53 (1860), 29-30.

3. "Neue Ausgaben von Schumann'schen Clavierwerken der ersten Periode," NZfM 54 (1861), 69-70, 78-79.

4. "Die gegenwärtige Musikepoche und Robert Schumann's Stellung in der Musikgeschichte," NZfM 54 (1861), 197-98, 205-06, 213-14.

5. "Die Schumann'sche Schule I. Carl Ritter," NZfM 55 (1861), 53-55.

6. "Die Schumann'sche Schule II. Theodor Kirchner," NZfM 55 (1861), 153-56, 165-67.

7. "Die Schumann'sche Schule III. Woldemar Bargiel," NZfM 55 (1861), 217-19, 225-27.

8. "Die Schumann'sche Schule IV. Johannes Brahms," NZfM 56 (1862), 93-96, 101-04, 109-12, 117-19, $125-28$.

9. "Polyglottische Ausgaben von Schumann's Op. 6, 13, und 14," NZfM 57 (1862), 13-14.

10. "Über Das und DAS, dieses und jenes, Schumann und Jean Paul," NZfM 59 (1863), 193-96.

11. "Die Schumann'sche Schule. Schumann und Brahms. Brahms's vierhändige Schumann-Variationen," Allgemeine Musikalische Zeitung 3 (1868), 41-42, 49-51.

12. "Ein Deutsches Requiem ... von Johannes Brahms," Allgemeine Musikalische Zeitung 4 (1869), 9$11,18-20$. 